\title{
Phytochemistry, GC-MS Analysis, Antioxidant and Antimicrobial Potential of Essential Oil From Five Citrus Species
}

\author{
Shabnam Javed ${ }^{1}$, Ayesha Javaid ${ }^{2}$, Shaista Nawaz ${ }^{3}$, M. K. Saeed ${ }^{3}$ Zaid Mahmood $^{2}$, S. Z. Siddiqui ${ }^{4} \&$ Rauf Ahmad $^{5}$ \\ ${ }^{1}$ Centre for Undergraduate Studies, University of the Punjab, Quaid-e-Azam Campus, Lahore-54590, Pakistan \\ ${ }^{2}$ Institute of Chemistry, University of the Punjab, Lahore, Pakistan \\ ${ }^{3}$ Food and Biotechnology Research center, Pakistan Council of Scientific and Industrial Research Laboratories \\ Complex, Ferozepur Road, Lahore, Pakistan \\ ${ }^{4}$ Department of Chemistry, Government College University, Lahore, Pakistan \\ ${ }^{5}$ Centre for environment protection studies, Pakistan Council of Scientific and Industrial Research Laboratories \\ Complex, Ferozepur Road, Lahore, Pakistan \\ Correspondance: Shabnam Javed, Centre for Undergraduate Studies, University of the Punjab, Quaid-e-Azam \\ Campus, Lahore-54590, Pakistan.Tel: 92-042-9923-2057. E-mail: shabnamjaved@yahoo.com
}

$\begin{aligned} & \text { Received: November 13, } 2013 \quad \text { Accepted: December 2, } 2013 \quad \text { Online Published: February 15, } 2014 \\ & \text { doi:10.5539/jas.v6n3p201 }\end{aligned}$ URL: http://dx.doi.org/10.5539/jas.v6n3p201

\begin{abstract}
Citrus essential oils were extraction from hydro distillation technique yielding Citrus oil with reasonable yield. Phytochemical screening of all five Citrus oils showed that alkaloids, tannins, sterols, terpenoids, saponoins, flavonoids were present (50-80\%). GC/MS analysis showed highest percentage of limonene (58-89\%) in Citrus oils. Antioxidant study revealed that Citrus peel oils have strong scavenging activity (83\%-91\%). Antimicrobial activity was evaluated by agar well method against eight common pathogens depicted marked antimicrobial potential especially tangerine $(4.9-1.9 \mathrm{~cm}$ inhibition zones) and grapefruit oil $(4.5-1.2 \mathrm{~cm})$ inhibition zones. The studies emphasized the therapeutic and commercial utilization of Citrus peel essential oils as food preservatives, phytomedicine and antioxidant agent.
\end{abstract}

Keywords: Citrus essential oils (EO), GC-MS analysis, phytochemicals, DPPH assay, antimicrobial activity

\section{Introduction}

All over the world Citrus is one of the widespread genus due to its prominent production. Citrus essential oils are naturally occurring, volatile and odoriferous oils synthesized by non woody parts of aromatic plants such as seeds, buds, leaves, flowers, stems, fruits, twigs and roots etc. and accumulated in secretory or epidermis cells and also sometimes in cavities (Ahmad, 2006). Essential oil from Citrus fruit peel is the fundamental product of genus Citrus and typically isolated by distillation or solvent extraction (Mondello et al., 2005). These are the complex mixtures of about 400 compounds of which $1-15 \%$ are non-volatile whereas $85-99 \%$ is the volatile constituents (Nannapaneni et al., 2009). Other organic compounds present in Citrus essential oils are aliphatic hydrocarbons, alcohols (linalool), aldehydes (citral), acids, esters and some aromatic compounds (Sharma \& Tripathi, 2006). Svoboda \& Greenaway (2003) reported the chief chemical constituent of Citrus essential oils is limonene and have a range of 32 to $98 \%$. Citrus essential oils act as natural antioxidants because flavanone glycosides namely naringin, narirutin, hesperidin and neohesperidin are valuable phenolic compounds found in Citrus peel oil which make them liable to avert rancidity of food (Anagnostopoulou et al., 2006).

Essential oils of Citrus peels are medicinally very important and show variety of biological effects because they are rich in flavonoids (flavone, flavonol and flavanone), terpenes, carotenes and coumarines which are responsible for antimicrobial activity (Tepe et al., 2005). Consequently Citrus essential oils are extensively used in pharmaceutics as an antimicrobial, anti-diabetic, antioxidant, insect repellent, carminative, larvicidal, antiviral, antihepatotoxic and antimutagenic agent (Kanaze et al., 2008).

The rapidly growing importance of Citrus based essential oils in food, pharmaceuticals, perfumes, flavor and fragrance has forced Pakistan to import increasing amounts of Citrus oils despite its rich variegated acreage of Citrus fruits and one of the largest Citrus fruits producing country of the world. These factors provide the 
opportunity for the production of highest grade essential oils from Citrus fruit peel. So there was an urgent need to focus on the extraction of essential oils as solid waste management and to improve our economy. This study was aimed for the assessment of phytochemical constituents, antioxidant as well as antimicrobial activities of five Citrus species, Citrus sinensis (L.) var. Malta, C. sinensis (L.) var. Mousami, C. reticulate (L.) var. Tangerine, $C$. reticulate (L.) var. Mandarin and $C$. paradisi (L.) Grapefruit.

\section{Materials and Methods}

\subsection{Collection and Identification of Citrus Fruit Peels}

Peels of five varieties of Citrus fruits were collected from local Citrus juice shop near University of the Punjab, Quaid-e-Azam campus, Lahore, Pakistan during the month of January \& February 2012. Voucher specimen number PU. HHC.901, PU.HHC.902, PU.HHC.903, PU.HHC.904 and PU.HHC. 905 were assigned to Malta, Mousami, Tangerine, Mandarin and Grapefruit respectively.

\subsection{Extraction of Citrus Essential Oil}

Essential oils of selected Citrus species was extracted by hydro distillation unit for 3-4 hours extraction. Mixture of Citrus oils and water was incorporated which was separated, in two liquid layers which was isolated. . Hydro-distilled pure oil obtained was stored in dark brown sealed vials at $4^{\circ} \mathrm{C}$ until analysis.

\subsection{Physicochemical and Phytochemical Investigation of Citrus EO}

Physicochemical characteristics of Citrus essential oils including refractive index, optical rotation, specific gravity, color, odor and solubility were analyzed by the method of AOAC (2005). The chemical tests were carried out for screening of bioactive compounds present in Citrus essential oils using standard methods (Sofowora, 1993; Trease \& Evans, 1989).

\subsection{GC-MS Analysis of Citrus EO}

Citrus essential oils were analyzed for their chemical composition by GC-MS analysis. GC/MS JOEL model JMS-A $\times 5050$ H mass spectrometer (JOEL, Japan) Hewlett Packard 5890 Gas Chromatograph (JOEL, Japan). Helium as carrier gas, split ratio 1:100, electrical energy $70 \mathrm{eV}$, ionization current $200 \mu \mathrm{A}$, ionization temperature $250^{\circ} \mathrm{C}$, column temperature with $6^{\circ} \mathrm{C} / \mathrm{min}$ rise to $230^{\circ} \mathrm{C}$. The chemical constituents were identified by their retention time and compared with known spectrum deposited in the National Institute Standard and Technology (NIST) library (NIST147.LIB).

\subsection{DPPH Assay}

Antioxidant potential was assessed by evaluating scavenging effect of each of five varieties of Citrus peel oils on DPPH. $500 \mu \mathrm{L}$ of each essential oil was added in $3 \mathrm{ml}$ of $0.002 \%$ methanolic solution of DPPH and shaken well. Absorbance was noted at $517 \mathrm{~nm}$ for all sample solutions and blank (contain only DPPH) after a stay time of 30 min in dark (Amin et al., 2006). All measurements were performed in triplicates. Scavenging potential of Citrus peel oils was determined in terms of percentage inhibition (I \%) of DPPH by given formula:

$$
\text { Percent inhibition }=\left(\mathrm{A}_{\text {blank }}-\mathrm{A}_{\text {sample }} / \mathrm{A}_{\text {blank }}\right) \times 100
$$

Where $A_{\text {blank }}$ represents absorbance of DPPH only at $517 \mathrm{~nm}$ and $A_{\text {sample }}$ represents absorbance of sample under investigation at $517 \mathrm{~nm}$.

\subsection{Antimicrobial Activity of Citrus Oils}

\subsubsection{Test Organisms}

Antimicrobial activity of Citrus peel essential oils were studied against the two Gram positive bacteria Listeria monocytogenesn and Corynebacterium minutissimum and three Gram negative bacteria Escherichia coli, Yersinia sp. and Klebsiella planticola whereas three fungal strains named as Aspergillus flavus, A. fumigates and A. niger were used. All microorganisms were obtained from First Fungal Culture Bank of Pakistan (FCBP), Institute of Agricultural Sciences, University of the Punjab, Lahore.

\subsubsection{Agar Well Diffusion Method}

Antimicrobial potential of Citrus peel essential oils was assessed using agar well method (Kim et al., 1995). Each microbial concentration was made $10^{6} \mathrm{CFU} / \mathrm{ml}$. Wells $(8 \mathrm{~mm})$ were prepared in plates (single well in case of fungi whereas four wells in case of bacteria). About $60 \mu \mathrm{L}$ of the essential oil was dripped into the wells. Water was used as control. The inoculated plates were incubated for 24 hours at $37^{\circ} \mathrm{C}$ for bacterial isolates and for $72 \mathrm{~h}$ at $27^{\circ} \mathrm{C}$ for fungi isolates. Study was conducted in triplicates. Biostatic efficacy against test organisms was investigated by measuring the inhibition zones in comparison to a control. 


\section{Results and Discussion}

\subsection{Yield of Citrus EO by Hydro Distillation}

For Citrus oil extraction by the hydro distillation, five batches of Citrus species were carried out to determine average productivity of Citrus oils (Table 1). Citrus oils yield were in the range of (0.28-0.45\%) for 3-4 hours extraction, comparable and better in some varieties as compared to other extraction techniques reported in literature (Minh Tu et al., 2002; Lota et al., 2000). The highest yield among all Citrus essential oil was calculated for $C$. paradise Grapefruit $0.45 \%$ followed by $C$. sinensis var. Malta $0.37 \%, C$. reticulate var. Mandarin $0.33 \%, C$. sinensis var. Mousami $0.30 \%$, C. reticulate var. Tangerine $0.28 \%$ (Table 1). According to the previous work of Minh Tu et al. (2002) the yield of orange essential oil was $0.13 \%$ and tangerine essential oil was $0.25 \%$. The essential oil yielded from various cultivars of mandarin was reported, $0.1 \%$ to $0.45 \%$ (Lota et al., 2000). Varying yields of essential oil are due to different extraction methods, units, soil and climatic conditions (Huet, 1991).

Table 1. Percentage yield of Citrus essential oils by fabricated unit

\begin{tabular}{|c|c|c|c|c|}
\hline $\begin{array}{l}\text { Citrus species } \\
\text { Essential oils (EO) }\end{array}$ & $\begin{array}{l}\text { Raw Material Input } \\
(\mathrm{g})\end{array}$ & $\begin{array}{l}\text { Time extract } \\
\text { (minutes) }\end{array}$ & $\begin{array}{l}\text { Oil volume } \\
(\mathrm{ml})\end{array}$ & $\begin{array}{l}\text { Productivity } \\
(\mathrm{ml} / 2000 \mathrm{~g}) \%\end{array}$ \\
\hline C. paradisi & 2000 & 215 & 9.0 & 0.45 \\
\hline C. sinensis var. Malta & 2000 & 230 & 7.5 & 0.37 \\
\hline $\begin{array}{l}\text { C. reticulate var. } \\
\text { Mandarin }\end{array}$ & 2000 & 210 & 6.6 & 0.33 \\
\hline $\begin{array}{l}\text { C. sinensis var. } \\
\text { Mousami }\end{array}$ & 2000 & 235 & 6.0 & 0.30 \\
\hline $\begin{array}{l}\text { C. reticulate var. } \\
\text { Tangerine }\end{array}$ & 2000 & 220 & 5.6 & 0.28 \\
\hline
\end{tabular}

\subsection{Physicochemical Characterization}

Specific gravity of Citrus essential oils in present work was ranged from 0.842-0.858, refractive indices between 1.465-1.476 and all essential oils were found optically active (Table 2). These results were in line with preceding work on essential oils of Citrus species (Guenther, 1948).

Table 2. Physicochemical properties of C. reticulate var. Mandarin, C. sinensis var. Mousami, C. paradisi, C. sinensis var. Malta, C. reticulate var. Tangerine

\begin{tabular}{|c|c|c|c|c|c|}
\hline \multirow{2}{*}{$\begin{array}{l}\text { Physical } \\
\text { Parameters }\end{array}$} & \multicolumn{5}{|c|}{ Citrus oils } \\
\hline & Mandarin & Mousami & Grapefruit & Malta & Tangerine \\
\hline Color & Yellow & Light yellow & Light yellow & Pale yellow & Light yellow \\
\hline Odour & $\begin{array}{l}\text { Pleasant, } \\
\text { Intense }\end{array}$ & $\begin{array}{l}\text { Pleasant, less } \\
\text { Intense }\end{array}$ & $\begin{array}{l}\text { Pleasant, less } \\
\text { Intense }\end{array}$ & $\begin{array}{l}\text { Pleasant, } \\
\text { Intense }\end{array}$ & $\begin{array}{l}\text { Pleasant, less } \\
\text { Intense }\end{array}$ \\
\hline $\begin{array}{l}\text { Refractive index } \\
\left(25^{\circ} \mathrm{C}\right)\end{array}$ & 1.465 & 1.471 & 1.476 & 1.471 & 1.468 \\
\hline $\begin{array}{l}\text { Optical rotation } \\
\left(25^{\circ} \mathrm{C}\right)\end{array}$ & +86 & +91 & +93 & +89 & +88 \\
\hline $\begin{array}{l}\text { Specific gravity } \\
\left(25^{\circ} \mathrm{C}\right)\end{array}$ & 0.844 & 0.849 & 0.858 & 0.847 & 0.842 \\
\hline \multicolumn{6}{|l|}{ Solubility } \\
\hline Water & Insoluble & Insoluble & Insoluble & Insoluble & Insoluble \\
\hline Ether & Soluble & Soluble & Soluble & Soluble & Soluble \\
\hline Acetone & Fairly Soluble & Fairly Soluble & Fairly Soluble & Fairly Soluble & Fairly Soluble \\
\hline
\end{tabular}




\subsection{Phytochemical Investigation}

Phytochemical screening of all tested Citrus peel oils gave presence of alkaloids, tannins, terpenoids, saponins and combined anthraquinones in significant amounts $(25-80 \%)$. Flavonoids and sterols were highly present in five Citrus essential oils (>80\%). Anthraquinones were moderately present (50-80\%) in essential oils of C. sinensis var. Mousami and Malta whereas highly depicted in C. paradisi, C. reticulate var. Tangerine and var. Mandarin $(>80 \%)$. In all Citrus essential oils, alkaloids were in the range of 50-80\%. Only C. paradisi peel oil depicted the presence of coumarin whereas all Citrus peel oils gave negative test for phlobatanins (Table 3). Mondello et al. (2005) explored flavonoids, terpenes, coumarins and carotenes as the major phytochemicals of Citrus essential oils. Likewise, Okwu et al. (2007) screened phytochemicals of five Citrus species and revealed the presence of saponins, tannins, flavonoids, alkaloids and phenols.

Table 3. Phytochemical Constituents of C. reticulate var. Mandarin, C. sinensis var. Mousami, C. paradisi, C. sinensis var. Malta, C. reticulate var. Tangerine

\begin{tabular}{llllll}
\hline \multirow{2}{*}{ Phytochemicals } & \multicolumn{5}{c}{ Citrus oils } \\
\cline { 2 - 6 } & Mandarin & Mosammi & Grapefruit & Malta & Tangerine \\
\hline Alkaloids & ++ & ++ & ++ & ++ & ++ \\
Tannins & + & + & ++ & + & +++ \\
Sterols & +++ & +++ & +++ & +++ & +++ \\
Terpenoids & ++ & + & ++ & ++ & +++ \\
Saponins & ++ & + & + & ++ & ++ \\
Flavonoids & +++ & ++ & +++ & +++ & +++ \\
Coumarins & - & - & + & - & - \\
Anthraquinones & +++ & ++ & +++ & ++ & +++ \\
Combined anthraquinones & ++ & + & ++ & + & ++ \\
Phlobatanins & - & - & ++ & - & - \\
\hline
\end{tabular}

$(-)=$ absent, $(+)=$ present, $>50 \%$, compared with control, $(++)=50 \%<80 \%,(+++)=>80 \%$.

\subsection{Chemical Composition by GC-MS Analysis}

Limonene was identified as the key element of Citrus peel oils. GC-MS analysis of Citrus peel oils revealed that among five Citrus essential oils, Grapefruit essential oil displayed highest concentration of limonene (89.84\%) followed by essential oils of Malta (88.57\%), Mousami (87.84\%), Mandarin (87.45\%) and Tangerine (58.50\%). Other chemical constituents identified were limonene oxide, $\alpha$-terpineol, carvone, carveol, eugenol, spathulenol and caryophyllene oxide. $\alpha$-Terpineol (12.55\%) was the second major component of all five Citrus essential oils with Mandarin peel oil containing highest of it (Table 4). These results were in line with the former work on Brazillian tangerinesin which limonene was the major component (Feger et al., 2003). Similarly, Espina et al., (2011) reported limonene $(85.50 \%)$ and $\alpha$-terpineol $(0.36 \%)$ as chief component of Citrus essential oils. In present study, apart from limonene (88.57\%) and $\alpha$-terpineol (8.45\%), Malta peel oil also contained eugenol $(0.58 \%)$, spathulenol $(0.55 \%)$, caryophyllene oxide $(0.99 \%)$, n-hexadecanoic acid $(0.86 \%)$. Tangerine peel oil showed presence of carvone (16.97\%), carveol (8.77\%), 3-cyclohexene-1-methanol (8.91\%) and limonene oxide (6.85\%) in addition to limonene (58.50\%). In Mousami peel oil, $\alpha$-terpineol (12.16\%) was major component after limonene (Table 4). Most of the compounds identified in Citrus peel oils were found to be hydrocarbons in nature (Ayoola et al., 2008). The major constituents of Citrus peel oils investigated by Vekiari et al., (2002) were limonene, neral, geranial, $\beta$-pinene, $\beta$-caryophyllene and neryl acetate. Preceding work stated limonene $(86.27 \%), \gamma$-terpinene $(2.11 \%)$ and $\alpha$-pinene $(1.26 \%)$ in Grapefuit peel essential oil and limonene (76.28\%), $\beta$-pinene $(5.45 \%)$, linalool (2.32\%), citral (1.74\%) and $\alpha$-pinene (1.26\%) in Mousami peel oil (Ahmad et al., 2006). The different chemical constituents of different Citrus species are assumed may be due to different genetic characteristics. 
Table 4. Chemical constituents of Citrus oils (GC-MS Analysis)

\begin{tabular}{llll}
\hline Citrus Essential oils (EO) & Retention time & Compounds & \% Area \\
\hline \multirow{2}{*}{ Mousami EO } & 7.215 & Limonene & 87.84 \\
& 8.867 & $\alpha$-terpineol & 12.16 \\
& 7.210 & Limonene & 88.57 \\
& 8.895 & $\alpha$-terpineol & 8.45 \\
Malta EO & 10.693 & Eugenol & 0.58 \\
& 11.417 & Spathulenol & 0.55 \\
& 11.486 & Caryophyllene oxide & 0.99 \\
Grapefruit EO & 13.935 & n-Hexadecanoic acid & 0.86 \\
& 7.215 & Limonene & 89.84 \\
Mandarin EO & 8.871 & $\alpha$-terpineol & 10.16 \\
& 7.216 & Limonene & 87.45 \\
& 8.893 & a-terpineol & 12.55 \\
Tangerine EO & 7.218 & Limonene & 58.50 \\
& 8.345 & Limonene oxide & 6.85 \\
& 9.096 & Carveol & 8.77 \\
& 9.332 & Carvone & 16.97 \\
& 10.152 & 3-Cyclohexene-1-methanol & 8.91 \\
\hline
\end{tabular}

\subsection{Antioxidant Activity}

Antioxidant study revealed that all the Citrus peel oils have strong potential to reduce DPPH radical to DPPH-H (83\%-91\%). Highest antioxidant activity was shown by $C$. raticulata var. Mandarin $(91.1 \%)$ followed by $C$. reticulate var. Tangerine $(88.0 \%)$, C. paradisi $(87.2 \%)$, C. sinensis var. Malta $(86.0 \%)$ and $C$. sinensis var. Mousami $83.2 \%$ for $500 \mu \mathrm{l} / \mathrm{ml}$ oil (Figure 1). Antioxidant efficacy of Citrus peel oils in decreasing order was as follows: Mandarin $>$ Grapefruit $>$ Tangerine $>$ Malta $>$ Mousami. These results were in accordance with work of Kamal et al. (2013) that $C$. reticulate var. Mandarin showed maximum antioxidant potential whereas $C$. sinensis var. Mousami showed minimum antioxidant potential. Correspondingly, Yang et al. (2010) reported limonene is a major constituent of Citrus peel oils having antioxidant potential equivalent to that of strong antioxidants.

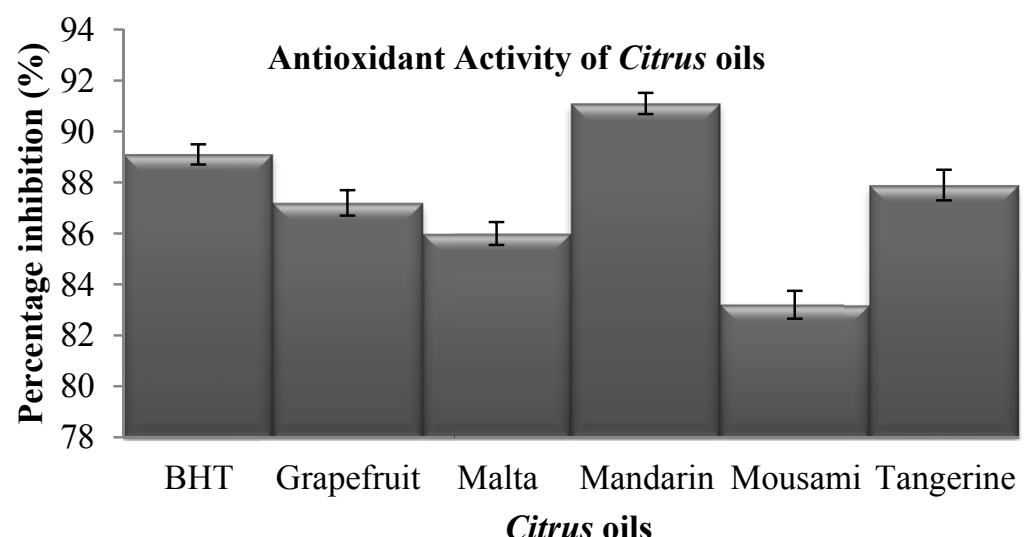

Citrus oils

Figure 1. Antioxidant activity of Citrus oils by DPPH assay using BHT as standard. Data expressed as \pm standard error bars 
(A)

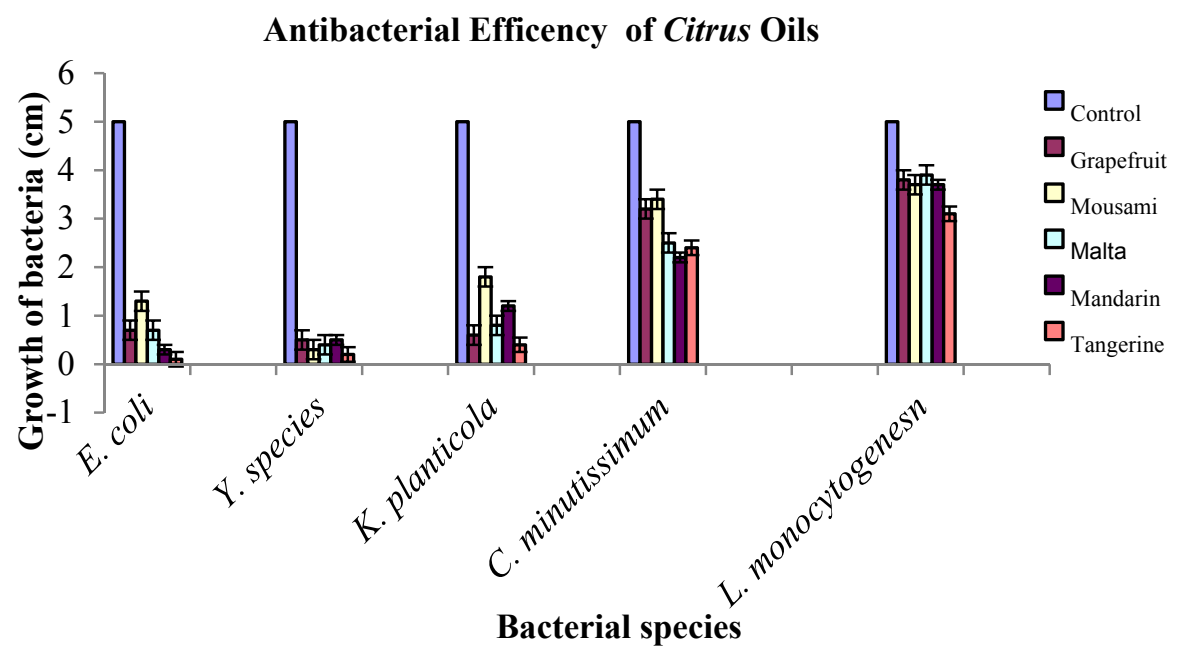

Antifungal Efficency of Citrus Oils

(B)

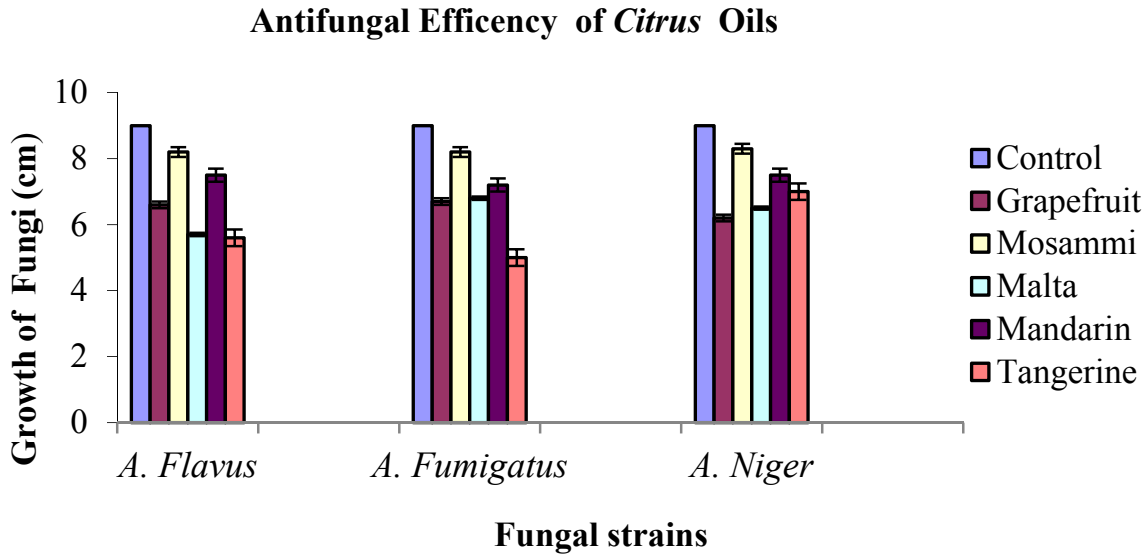

Figure 2. Antimicrobial activity of Citrus oils (A) Antibacterial activity of Citrus oils against five bacterial species (B) Antifungal activity of Citrus oils against three fungal pathogens. Error bars specify the mean \pm standard error

\subsection{Antimicrobial Activity}

The antimicrobial activity of Citrus sinensis(L.) var. Malta and Mousami, Citrus reticulate (L.) var. Tangerine and Mandarin and Citrus paradise (L.) grapefruit was examined on five bacterial strains L. monocytogenesn, $C$. minutissimum, E. coli, Y. sp. and K. planticola (Figure 2A). The essential oils had various degrees of inhibition potential against the five bacterial strains. Tangerine oil depicted maximum bacteriostatic activity against all the test bacteria i.e., E. coli, $Y$. sp. K. planticola, L. monocytogenesn with inhibition zones $(4.9 \mathrm{~cm}, 4.8 \mathrm{~cm}$ and $4.6 \mathrm{~cm}$ and $1.9 \mathrm{~cm}$, respectively) except $C$. minutissimum var. Mandarin essential oil revealed second highest inhibitory potential against $E$. coli and $C$. minutissimum $(4.7 \mathrm{~cm}$ and $2.8 \mathrm{~cm})$ while Mousami oil against both $L$. monocytogenesn $(1.3 \mathrm{~cm})$ and $Y$. sp. $(4.7 \mathrm{~cm})$. Grapefruit essential oil displayed marked bactericidal activity against $K$. planticola depicting the inhibition zone of $4.4 \mathrm{~cm}$. Least antibacterial effect was shown by Mousami in case of C. minutissimum, E. coli and $K$. planticola $(1.6 \mathrm{~cm}, 3.7 \mathrm{~cm}$ and $3.2 \mathrm{~cm}$, respectively), whereas Grapefruit and Mandarin against $Y$. sp. ( $4.5 \mathrm{~cm}$ each). The growth of $L$. monocytogenesn was least affected by Malta oil (1.1 $\mathrm{cm})$. C. minutissimum and L. monocytogenesn were least susceptible to growth inhibition by Citrus essential oils. The antimicrobial activities of Citrus species are strongly related with chemical constituents like flavonoids and phenols (Viuda-Martos et al., 2008). The active ingredients responsible for antimicrobial potential of Citrus peel oils are monoterpene components (Pavithra et al., 2009). D-limonene, linalool or citral are major attributors for the antimicrobial capacity of Citrus peel oils. Previous work revealed that the inhibitory influence of Citrus peel essential oils is owed to the presence of linalool rather than limonene (Fisher \& Phillips, 2006). However it has 
been found that antimicrobial activity is not only produced by one particular major component but also due to the antagonistic and synergistic effects of variety of compounds (Deba et al., 2008).

The essential oils of Grapefruit, Mousami, Malta, Mandarin and Tangerine showed the tendency to impede the growth of molds A. flavus, A. fumigates and A. niger (Figure 2B). In all molds, Tangerine and Grapefruit oils revealed great antifungal potentials. In case of A. flavus and A. fumigatus, Tangerine peel oil was the best growth inhibitor $(3.4 \mathrm{~cm}-4.0 \mathrm{~cm})$. Followed by Grapefruit and Malta peel oils, which showed almost equal reduction in growths for these two molds. Mandarin and Mousami showed the lowest growth reductions of A. flavus and A. fumigatus. The mycelium growth of $A$. niger was most susceptible to grapefruit essential oil with inhibition zone $(2.8 \mathrm{~cm})$ while least affected by mousami peel oil with inhibition zone $(0.7 \mathrm{~cm})$. Viuda-Martos et al. (2008) studied inhibitory influence of mandarin, orange and grapefruit peel essential oils on four fungal pathogens. A. flavus growth was best prevented by Mandarin essential oil whereas $A$. niger growth was most susceptible to Orange peel oil. Grapefruit essential oil was the most efficient against $P$. verrucosum and $P$. chrysogenum.

\section{Conclusion}

The results of present investigation are the basis for extraction of essential oil of Citrus by cheaper methods to design pilot plant to extract EO for industrial production. Some major restraints in viable industrial exploitation of medicinal plants are due to the poor agricultural practices, quality control trials, strain in marketing and dearth of research on process and product development. Coordination among various institutes and organizations of the country can lead for sustainable commercial utilization.

\section{References}

A. O. A. C. (2005). Official methods of Analysis (15th ed.). Association of Official Analytical Chemists, Washington DC.

Ahmad, M. M., Rehman, S., Iqbal, Z., Anjum, F. M., \& Sultan, J. I. (2006). Genetic variability to essential oil composition in four Citrus fruit species. Pakistan Journal of Botany, 38, 319-324.

Amin, I., Norazaidah, Y., \& Emmy Hainida, K. I. (2006). Antioxidant activity and phenolic content of raw and blanched Amaranthusspecies. Food Chemistry, 94, 47-52. http://dx.doi.org/10.1016/j.foodchem.2004.10.048

Anagnostopoulou, M. A., Kefalas, P., Papageorgiou, V. P., Assimopoulou, A. N., \& Boskou, D. (2006). Radical scavenging activity of various extracts and fractions of sweet orange peel (Citrus sinensis). Food Chemistry, 94, 19-25. http://dx.doi.org/10.1016/j.foodchem.2004.09.047

Ayoola, G. A., Johnson, O. O., Adelowotan, T., Aibinu, I. E., Adenipekun, E., Adepoju-Bello, A. A., ... Odugbemi, T. O. (2008). Evaluation of the chemical constituents and the antimicrobial activity of the volatile oil of Citrusreticulatafruit (Tangerine fruit peel) from South West Nigeria. African Journal of Biotechnology, 7(13), 2227-2231.

Deba, F., Xuan, T. D., Yasuda, M., \& Tawata, S. (2008). Chemical composition and antioxidant, antibacterial and antifungal activities of the essential oils from Bidenspilosa Linn. Var. Radiata. Food Control, 19, 346-352. http://dx.doi.org/10.1016/j.lwt.2007.04.011

Espina, L., Somolinos, M., Lorán, S., Conchello, P., García, D., \& Pagán, R. (2011). Chemical composition of commercial Citrus fruit essential oils and evaluation of their antimicrobial activity acting alone or in combined processes. Food Control, 22, 896-902. http://dx.doi.org/10.1016/j.foodcont.2010.11.021

Feger, W., Brandauer, H., \& Ziegler, H. (2003). Analytical investigation of Murcott (Honey) tangerine peels oil. Journal of Essential Oil Research, 15(3), 143-147. http:// dx.doi.org/10.1080/10412905.2003.9712097

Fisher, K., \& Phillips, C. A. (2006). The effect of lemon, orange and bergamot essential oils and their components on the survival of Campylobacter jejuni, Escherichia coli O157, Listeria monocytogenes, Bacillus cereus and Staphylococcus aureus in vitro and in food systems. Journal of Applied Microbiology, 101, 1232-1240. http://dx.doi.org/10.1111/j.1365-2672.2006.03035.x

Guenther, E. (1948). The Essential Oils. The examination and analysis of essential oils, synthetics, and isolates (pp. 229-367). New York: Van D. Nostrand Company Inc.

Huet, R. (1991). Les huillesessentielles d' agrumes. Fruits, 46(5), 551-576.

Kamal, G. M., Ashraf, M. Y., Hussain, A. I., Shahzadi, A., \& Chughtai, M. I. (2013). Antioxidant potential of peel essential oils of three Pakistani Citrus species: Citrus reticulata, Citrus sinensisand Citrus paradisii. Pakistan Journal of Botany, 45(4), 1449-1454 
Kanaze, F. I., Termentzi, A., Gabrieli, C., Niopas, I., Georgarakis, M., \& Kokkalou, E. (2008). The phytochemical analysis and antioxidant activity assessment of orange peel (Citrus sinensis) cultivated in Greece-Crete indicates a new commercial source of hesperidin. Biomedical Chromatography, 23, 239-249. http://dx.doi.org/10.1002/bmc.1090

Kim, J., Marshall, M. R., \& Wei, C. I. (1995). Antibacterial activity of some essential oil components against five food borne pathogens. Journal of Agriculture and Food Chemistry, 43, 2839-2845. http://dx.doi.org/10.1021/jf00059a013

Lota, M. L., De Rocca Serra, D., Tomi, F., \& Casanova, J. (2000). Chemical variability of peel and leaf essential oils of mandarins from Citrus reticulata Blanco. Biochemical Systematics and Ecology, 28, 61-78. http://dx.doi.org/10.1016/S0305-1978(99)00036-8

Minh Tu, N. T., Thanh, L. X., Une, A., Ukeda, H., \& Sawamura, M. (2002).Volatile constituents of Vietnamese pummelo, orange, tangerine and lime peel oils. Flavour and Fragrance Journal, 17, 169-174. http://dx.doi.org/10.1002/ffj.1076

Mondello, L., Casilli, A., Tranchida, P. Q., \& Dugo, P. (2005). Comprehensive two-dimensional GC for the analysis of Citrus essential oils. Flavour and Fragrance Journal, 20, 136-140. http://dx.doi.org/10.1002/ffj.1506

Nannapaneni, R., Chalova, V. I., Crandall, P. G., Ricke, S. C., Johnson, M. G., \& O’Bryan, C. A. (2009). Campylobacter and Arcobacter species sensitivity to commercial orange oil fractions. International Journal of Food Microbiology, 129(1), 43-49. http://dx.doi.org/10.1016/j.ijfoodmicro.2008.11.008

Okwu, D. E., Awurum, A. N., \& Okoronkwo, J. I. (2007). Phytochemical composition and in vitro antifungal activity screening of extracts from Citrus plants against Fusarium Oxysporum of Okra plant (Hibiscus esculentus). African Crop Science Conference Proceedings, 8, 1755-1758.

Pavithra, P. S., Sreevidya, N., \& Verma, R. S. (2009). Antibacterial activity and chemical composition of essential oil of Pamburusmissionis. Journal of Ethnopharmacology, 124, 151-153. http://dx.doi.org/10.1016/j.jep.2009.04.016.

Sharma, N., \& Tripathi, A. (2006). Effects of Citrus sinensisepicarp essential oil on growth and morphogenesis of Aspergillusniger Van Tieghem. Microbiological Research, 10, 1016-1020.

Sofowora, A. E. (1993). Medicinal Plants and Traditional Medicine in Africa (p. 288). Ibadan, Nigeria: Spectrum Books Ltd.

Svoboda, K. P., \& Greenaway, R. I. (2003). Lemon scented plants. International Journal of Aromatherapy, 13(1), 23-32. http://dx.doi.org/10.1016/S0962-4562(03)00048-1

Tepe, B., Daferera, D., Sokmen, A., Sokmen, M., \& Polissiou, M. (2005).Antimicrobial and antioxidant activities of the essential oils and various extracts of Salvia tomentosaMiller (Lamiaceae). Food Chemistry, 90, 333-340. http://dx.doi.org/10.1016/j.foodchem.2003.09.013

Trease, G. E., \& Evans, W. C. (1989). Pharmacognosy (2nd ed.). Braille Tiridel and Macmillan Publishers.

Vekiari, S. A., Protopapadakis, E. E., Parthena, P., Dimitrios, P., Panou, C., \& Vamvakias, M. (2002). Composition and seasonal variation of the essential oil from leaves and peel of a Cretan lemon variety. Journal of Agricultural Food Chemistry, 50(1), 147-153. http://dx.doi.org/10.1021/jf001369a

Viuda-Martos, M., Ruiz-Navajas, Y., Fernandez-Lo'pez, J., \& Perez-Alvarez, J. (2008). Antifungal activity of lemon (Citrus lemon L.), mandarin (Citrus reticulataL.), grapefruit (CitrusparadisiL.) and orange

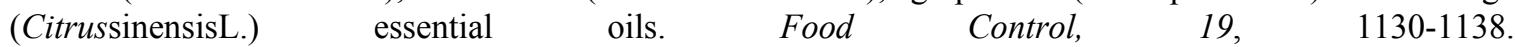
http://dx.doi.org/10.1016/j.foodcont.2007.12.003

Yang, S. A., Jeon, S. K., Lee, E. J, Shim, C. H., \& Lee, I. S. (2010). Comparative study of the chemical composition and antioxidant activity of six essential oils and their components. Natural Product Research, 24, 140-151. http://dx.doi.org/10.1080/14786410802496598

\section{Copyrights}

Copyright for this article is retained by the author(s), with first publication rights granted to the journal.

This is an open-access article distributed under the terms and conditions of the Creative Commons Attribution license (http://creativecommons.org/licenses/by/3.0/). 